\title{
Relapse in pituitary adenoma after resection
}

\author{
Nur Rochmah ${ }^{1 *}$, Frida Soesanti ${ }^{2}$, Aman B Pulungan², Bambang Tridjaja ${ }^{2}$, Jose RL Batubara ${ }^{2}$ \\ From 7th APPES Biennial Scientific Meeting \\ Nusa Dua, Bali. 14-17 November 2012
}

Pituitary adenoma in children is rarely reported. Acromegaly is one of clinical manifestation in $\mathrm{GH}$ releasing-pituitary adenoma. Recurrence of clinical manifestation after resection must be evaluated for possibility of pituitary adenoma relapse.

$\mathrm{N}$,male,15-yo, came to pediatric endocrinology outpatient clinic with the main complain of acromegaly and decreased of visual field which was getting worse since two weeks before(April11, 2011). He was consulted to ophthalmology and neurosurgery outpatient clinic. MRI with contrast revealed pituitary adenoma. Laboratories results showed TSHS:0.9773(0.35-4.94)uIU/ml, prolactin:0.51(4.04-15.2) ng/ml, testosterone less than 2.50 (boys:13-17:28-1110) ng/ml, growth hormone was more than $40,00(>10.0) \mathrm{ng} / \mathrm{ml}$. He was performed transsphenoidal removal cystic tumor. Pathological result showed macroscopic: yellowish cystous mass; $0.6 \times 0.4 \times 0.2 \mathrm{~cm}$ whether microscopic: appropiate to pituitary adenoma, non chromophobe. After surgery, patient was given DDAVP nasal spray 10 microgram/day, L-thyroxin 100 microgram once daily. One year after surgery, patient complaint of acromegaly, decreased visual field, especially in right and left temporal side, cephalgia. On physical examination, body weight was $91.5 \mathrm{~kg}$, height was $184.5 \mathrm{~cm}$. There was hemianopsia bitemporal. Tanner stage was A2P4G4. MRI with contrast showed pituritary adenoma relapse. Bone age was normal with height percentage based on it is about $96.8 \%$. Tanner Whitehouse showed adult height $186.4 \mathrm{~cm}$. Thorax $\mathrm{X}$ ray showed heart and lungs were normal. Laboratories results revealed IGF1:1359(237-996)microgram/L, FT4:1(0.89-1.76)ng/ dl; TSHS:0.3(0.5-4.94) microIU/ml(12-18yo), testosterone:435.1(28-1110) ng/dl. Working diagnosis was pituitary adenoma relapse post tumor resection, panhypopituitarism, diabetes insipidus. Testosterone $150 \mathrm{mg}$ once per month was added. Relapse of pituitary adenoma in

'Department of Child Health Medical School of Airlangga University-Dr Soetomo Hospital Surabaya, Indonesia

Full list of author information is available at the end of the article children must be considered in the recurrence of clinical manifestations.

\begin{abstract}
Authors' details
${ }^{1}$ Department of Child Health Medical School of Airlangga University-Dr Soetomo Hospital Surabaya, Indonesia. ${ }^{2}$ Department of Child Health Medical School of University of Indonesia-Ciptomangunkusumo National Hospital Jakarta, Indonesia.
\end{abstract}

Published: 3 October 2013

doi:10.1186/1687-9856-2013-S1-P199

Cite this article as: Rochmah et al:: Relapse in pituitary adenoma after resection. International Journal of Pediatric Endocrinology 2013 2013(Suppl 1):P199.
Submit your next manuscript to BioMed Central and take full advantage of:

- Convenient online submission

- Thorough peer review

- No space constraints or color figure charges

- Immediate publication on acceptance

- Inclusion in PubMed, CAS, Scopus and Google Scholar

- Research which is freely available for redistribution

Submit your manuscript at www.biomedcentral.com/submit
() Biomed Central

\section{(Ciomed Central}

